\title{
PERANCANGAN KEMASAN PRODUK RUMAH MAKAN PATINKU DI MEDAN
}

\author{
John $^{1}$, Asril' ${ }^{2}$, Agung Eko Budi Waspada ${ }^{3}$ \\ ${ }^{1}$ Program Studi Desain Komunikasi Visual, Fakultas Seni dan Desain, \\ Universitas Potensi Utama Medan \\ ${ }^{2}$ Program Studi Karawitan, Fakultas Seni Pertunjukkan, \\ Institut Seni Indonesia Padangpanjang \\ ${ }^{3}$ Program Studi Desain Komunikasi Visual, Fakultas Seni Rupa dan Desain, \\ Institut Teknologi Bandung \\ 1john_tang01@ymail.com, ${ }^{2}$ asrilmuchtar2017@gmail.com, ${ }^{3}$ agungebw83@yahoo.com
}

\begin{abstract}
ABSTRAK
Medan sangat kaya dengan berbagai jenis kuliner, di mana jenis makanan dari berbagai daerah ada di sana. Namun untuk kemasan produk makanan tersebut masih tidak semuanya memilikinya. Kemasan adalah salah satu yang dibutuhkan untuk bersaing dan menarik minat konsumen, dimana desain kemasan produk selain berfungsi sebagai pelindung produk tetapi juga sebagai sarana komunikasi untuk menyampaikan citra suatu perusahaan (usaha). Rumah Makan Patinku yang berada di Kota Medan adalah rumah makan yang memiliki ciri khas makanan tradisional dengan produk unggulan rumah makan tersebut adalah ikan patin. Oleh karena itu perancangan desain kemasan produk sangat berpengaruh untuk berkomunikasi dengan masyarakat dalam menyampaikan citra Rumah Makan Patinku. Konsep utama yang digunakan Rumah Makan Patinku adalah daun pisang sebagai ide kreatif mendesain kemasan. Desain kemasan menggunakan penelitian ilmiah yaitu studi literatur, observasi, dan juga teknik analis SWOT, sehingga dihasilkan rancangan yang sesuai dengan citra dan ciri khas Rumah Makan Patinku. Desain kemasan yang diciptakan adalah pembungkus nasi, kotak nasi, kotak ikan patin bakar, kantong kertas (paper bag), stiker pack plastik kontainer, cup jus minuman, dan kantong plastik.
\end{abstract}

Kata Kunci : Kemasan, Perancangan, Rumah Makan Patinku

\begin{abstract}
Medan is very rich with various of culinary, where various of food from different places are there. But for the packaging of food are still not all have it. Packaging is one that is needed to compete and attract consumers, where packaging design in addition to functioning as a product wrapping but also as a means of communication to convey the image of a company (business). Rumah Makan Patinku in Medan City is a restaurant that has characteristic of traditional food with special product of the restaurant is patin fish. Therefore packaging design is very influential to communicate with people in conveying the image of Rumah Makan Patinku. The main concept which is used Rumah Makan Patinku is banana leaves as a creative idea of packaging design. These product packaging design use scientific research are literature study, observation, and also SWOT analyst technique, so that the result of designed according to the image and characteristic of Rumah Makan Patinku. Packaging designs that are created are rice wrappers, rice boxes, ikan patin bakar boxes, paper bags, plastic pack, containers, cup juice, and plastic bags.
\end{abstract}

Keywords: Design, Packaging, Rumah Makan Patinku 


\section{PENDAHULUAN}

Rumah Makan Patinku berdiri sejak tahun 1980, namun dahulu tidak memiliki nama rumah makan. Rumah makan tersebut didirikan oleh seorang warga keturunan Thionghoa bernama Eng Hock yang menjadi mualaf ketika menikahi istrinya seorang pribumi keturunan Belanda dan Banten bernama Susilani. Rumah Makan Patinku sudah banyak mengalami perubahan produk yang dijual dari nasi goreng hingga es campur, namun akhirnya pada tahun 2007 rumah makan tersebut memiliki nama seperti sekarang yakni Rumah Makan Patinku.

Ciri khas dari produk kuliner dari rumah makan tersebut adalah olahan ikan patin. Ikan patin selalu identik dengan olahan khas Melayu, tetapi dengan keahlian Eng Hock dan istrinya mereka membuat suatu perkembangan baru di dunia kuliner, beliau menghasilkan jenis kuliner yang saat ini sangat banyak penggemarnya yakni Ikan Patin Bakar, Ikan Patin Steam, Ikan Patin Tauco, Ikan Patin Goreng (dengan olahan bawang putih). Rumah Makan tersebut juga menyediakan minuman berbagai jenis seperti aneka jus dan minuman lainnya.

Penulis melihat untuk membungkus ikan patin yang panjangnya antara $40 \mathrm{~cm}-42 \mathrm{~cm}$ masih tetap menggunakan pembungkus nasi sehingga kadang kala ekor ikan patin tersebut masih kelihatan keluar dari pembungkusnya. Begitu juga dengan ikan patin steam yang memiliki kuah namun kuah tersebut dibungkus terpisah dalam plastik yang lain, sehingga kurang menarik dari segi visual. Pembungkus tersebut tidak mencitrakan kesan atau makna dalam penyampaian pesan rumah makan tersebut, yakni "Makan bukan hanya sekedar kenyang, tetapi ada rasa kebersamaan dan sehat." Rasa kebersamaan dapat dilihat dengan ikan yang besar untuk menyantapnya lebih nikmat dengan bersama orang-orang dekat di sekitar kita, serta sehat karena ikan patin banyak mengandung gizi yang tinggi dan bebas kolesterol sehingga sangat baik dikonsumsi baik dari anak-anak sampai dengan orang dewasa.

Hal yang menjadi fokus utama, yakni mengenai kehigienisan makanan tersebut apabila dibawa dengan jarak yang jauh, tidak lupa juga penyampaian pesan atau makna dari olahan tersebut tertuang di dalam kemasan. Beberapa pelanggan juga berpendapat seharusnya ikan yang begitu besarnya dikemas dengan rapi, menarik, dan disesuaikan dengan olahannya, diharapkan nantinya dapat menjadi oleh-oleh khas Kota Medan yang baru.

\section{I.1. Kemasan}

Menurut Kontler dan Amstrong, Pengemasan adalah kegiatan merancang dan memproduksi wadah atau pembungkus suatu produk. Bungkus atau kemasan yang menarik akan memberikan nilai tambah pada pandangan konsumen, mereka dapat membedakan beberapa produk yang mutu dan bentuknya hampir sama. Perbedaan tersebut akan terlihat dari label/merk yang biasanya dalam kemasan produk. (Kontler dan Amstrong, 2008:275).

Kemasan lebih tertuju pada objek fisik itu sendiri, misalnya karton, botol, kontainer atau bungkus. Sebuah kemasan dapat berbentuk bungkus permen, dan botol shampoo. Istilah kemasan merupakan kata benda suatu objek, sedangkan mengemas merupakan kata kerja yang mencerminkan sifat medium yang selalu berubah. (Klimchunk dan Krasovec, 2007:34) 
Kemasan dapat dikatakan sebagai cover atau sampul luar dari produk yang dijual di dalamnya, kemasan juga menjadi wajah yang ditawarkan produsen sehingga jika tampilan wajah yang ingin dijual kurang menarik bagaimana konsumen ingin membelinya. Kemasan juga mewakili kualitas dari produk yang dijual sehingga kemaan menjadi sangat penting untuk dirancang, agar harga produk di dalamnya menjadi lebih bernilai.

Rancangan kemasan yang didesain haruslah juga menampilkan citra dari perusahaan atau usaha yang dijalankan. Melalui penyampaian citra produk dan usaha maka masyarakat dapat menilai dengan pandangan kualitas yang baik pula terhadap produk dan perusahaan yang membuatnya.

\section{I.2. Produk}

Pengertian produk (product) menurut Kotler dan Armstrong, (2008: 346) adalah segala sesuatu atau jasa yang dapat ditawarkan ke pasar untuk mendapatkan perhatian, dibeli, digunakan, atau dikonsumsi yang dapat memuaskan keinginan atau kebutuhan. Secara konseptual produk adalah pemahaman subyektif dari produsen atas sesuatu yang bisa ditawarkan sebagai usaha untuk mencapai tujuan organisasi melalui pemenuhan kebutuhan dan kegiatan konsumen, sesuai dengan kemampuan dan kapasitas organisasi serta daya beli pasar.

Selain itu produk dapat pula didefinisikan sebagai persepsi pemenuhan konsumen yang dijabarkan oleh produsen melalui hasil produksi yang dijualnya. Produk dipandang penting oleh konsumen dan dijadikan dasar pengambilan keputusan pembelian. Produk ada yang sebagai pemenuhan kebutuhan, namun juga ada yang hanya sebagai pelengkap kebutuhan.

Dari beberapa pengertian di atas pengkarya menyimpulkan perancangan kemasan produk adalah proses merancang wadah atau pembungkus suatu produk yang menarik untuk menambah nilai jual produk dan dapat menyampaikan pesan atau kesan dari suatu usaha yang akan dijual atau dipasarkan. Kemasan produk itu nantinya dapat menarik minat pembeli untuk memilih produk akan dijual atau dipasarkan.

\section{STUDI LITERATUR}

\section{II.1. Perancangan Kemasan Produk Perawatan Kulit Gizi Indonesia}

Penelitian karya Apsari Wiba Pamela dan Oki Hamka Suyatna Tahun 2014. Dalam penelitiannya para peneliti memaparkan mulai dari awal mula munculnya produk Gizi Indonesia sampai dengan melakukan perancangan produk untuk Gizi Indonesia. Pamela dan Oki menjadikan benda-benda yang ada di sekitarnya untuk dijadikan inspirasi kreatifnya dalam merancang desain kemasan seperti, corak bunga yang ada di sarung bantal, sprei, hiasan bunga di ruang tamu, dan lain-lain. Pengkarya juga banyak terinspirasi dari keseharian wanita yang disesuaikan kepada produk yang ditujukan untuk wanita, seperti bagian wanita, fashion dan majalah-majalah wanita seperti, majalah Shaby Chic. Pengkarya juga terinspirasi dari kafe atau konsep-konsep pernikahan yang sering dilihat dan dikunjunginya.

\section{II.2. Perancangan Kemasan Inovatif Gado-Gado Arjuna Pak Satumin Surabaya}


Pada penelitian perancangan kemasan gado-gado tersebut Handojo, et al., pada tahun

2016 melakukan perancangan ulang untuk kemasan awal dari produk tersebut, yang sebelumnya produk tersebut hanya seperti produk jajanan tradisional yang biasa-biasa saja. Namun setelah dilakukan perancangan kemasan produk yang baru jajanan tersebut kelihatan mewah namun tidak meninggalkan ciri khas tradisionalnya dengan pemilihan logo dan rancangan gambar luar kemasan yang identik dengan ciri khas Jawa.

Melalui perancangan tersebut Handojo, et al., membuat kemasan yang sangat unik di mana pada awalnya bumbu dari gado-gado tersebut yang dibungkus terpisah dan diletakkan di luar kotak. Namun setelah dirancang kemasan produk yang baru bumbu yang terpisah dari kemasan sudah bisa diletakkan di dalam kemasan kotak.

\section{II.3. Perancangan Desain Kemasan Produk Ledre Nyonya Seger}

Penelitian karya dari Jovita Christina, et al., pada tahun 2017 dalam penciptaannya bertujuan memberikan nilai perlindungan terhadap produk dengan menambahkan peranan estetika dan identitas melalui perancangan desain kemasan yang baru. Christina, et al., melakukan proses penciptaan dengan menggunakan metode kualitatif untuk menentukan SWOT. SWOT adalah singkatan dari Strength (kekuatan atau keunggulan produk), Weakness (kelemahan produk), Opportunity (keunikan produk yang tidak dimiliki produk lain), Threat ( pesaing atau competitor produk ). Analisis data yang didapat juga melalui wawancara dan observasi langsung ke lapangan, hal ini bertujuan mengetahui masalah utama yang dihadapi, sehingga Christina, et al., dapat memberikan solusi untuk permasalahan tersebut.

\section{III.PEMBAHASAN}

Perancangan kemasan produk Rumah Makan Patinku didasarkan pada untuk menambah nilai jual serta penyampaian citra Rumah Makan Patinku. Perancangan kemasan Rumah Makan Patinku dilakukan dengan melakukan tahapan-tahapan perancangan sebagai berikut: ttudi pustaka, observasi yang dilanjutkan wawancara, analisis data, penggrafisan, penempahan bahan kemasan dipercetakan.

\section{III.1. Studi Pustaka}

Pada tahapan ini, studi pustaka dilakukan untuk mendapatkan sumber yang berkaitan dengan teori untuk disesuaikan dengan topik karya yang akan dikerjakan. Buku-buku yang menjadi literatur dalam perancangan produk kemasan, yaitu buku Pengantar Desain komunikasi Visual dikarang oleh Adi Kusrianto (2007). Buku ini membahas mengenai pengenalan desain komunikasi visual, mengawali desain dengan nirmana, prinsip semiotik untuk desainer grafis, mengenal desain grafis, ilustrasi, komik, sastra gambar, tipografi, logo sampai dengan menyampaikan pesan melalui berbagai media iklan.

Dalam proses penciptaan karya ini, pengkarya tidak terlepas menggunakan metode riset. Oleh karena itu, pengkarya menggunakan buku Metode Riset untuk Desain Komunikasi Visual yang ditulis oleh Jonathan Sarwono dan Hary Lubis (2007). Buku ini berisi mengenai metode untuk berpikir dalam desain, yang membahas bagaimana cara-cara berpikir untuk 
mendapatkan ide-ide gagasan yang nantinya dijadikan sebagai sumber kreativitas dalam berkarya. Buku ini juga menjelaskan beberapa metode analisis untuk eksplorasi dan evaluasi untuk mengumpulkan data yang nantinya dijadikan referensi penciptaan karya.

Buku karangan Marianne Rosner Klimchuk dan Sandra A. Krasovec, yang berjudul, Desain Kemasan dalam buku ini dibahas mengenai cara merancang desain kemasan, merek produk yang membahas tentang konsep sampai penjualan. Buku ini juga memberikan pengertian apa itu desain kemasan.

Desain Kemasan adalah bisnis kreatif yang mengaitkan bentuk, struktur, material, warna, citra, tipografi (huruf), dan elemen-elemen desain dengan informasi produk agar produk dapat dipasarkan. Desain mengidentifikasi dan membedakan sebuah produk di pasar. Pada akhirnya desain kemasan berlaku sebagai pemasaran produk dengan mengkomunikasikan kepribadian atau fungsi produk konsumsi secara unik. (Klimchuk dan Krasovec, 2008:33)

\section{III.2. Observasi dilanjutkan wawancara}

Tahap selanjutnya menggunakan teknik observasi, menurut Supardi (2006:88) observasi dilakukan untuk mengamati dan mencatat secara sistematik gejala-gejala yang diselidiki. Observasi dilakukan ke Rumah Makan Patinku. Pada saat observasi pengkarya juga melakukan wawancara. Teknik wawancara yang digunakan, yaitu wawancara terstruktur. Menurut (Moleong, 1996:138), wawancara terstruktur merupakan proses menggali informasi secara mendalam, terbuka, dan bebas terhadap masalah serta fokus penelitian diarahkan pada pusat penelitian. Metode wawancara terstruktur dilakukan dengan adanya pertanyaan yang telah dipersiapkan sebelumnya.

Tahap berikutnya menggunakan teknik wawancara kepada pemilik usaha Rumah Makan Patinku dan beberapa pembeli di rumah makan tersebut. Wawancara dilakukan untuk mendapatkan informasi yang akurat dan berkualitas.Pada tahap observasi dan wawancara selain mengumpulkan data, penulis juga belajar bagaimana mengolah kuliner yang dijual di Rumah Makan Patinku.

Tahapan dimulai dengan mengambil ikan di tempat penjualan ikan Patin, ikan Patin yang dibeli harus dalam keadaan hidup agar menjaga kebersihan dan kehigienisan ikan. Kemudian membersihkan ikan hingga menyimpan di dalam peti es yang dikubur dengan es batangan yang sudah diserut, hal ini untuk mengurangi lendir lemak ikan yang berlebihan, selanjutnya baru mulai dengan pengolahan ikan Patin dengan berbagai jenis olahan.

\section{III.3. Analisis Data}

\section{III.3.1. Analisis SWOT}

Melalui hasil observasi danTeknik ana wawancara untuk mengumpulkan data pengkarya melakukan analisis data sebelum masuk ke tahap perancangan dan penggrafisan. Teknik analisis yang pengkarya gunakan adalah metode analisis SWOT (strenghts, weakness, opportunities, and thearts), yaitu :

a. Strenghts (kekuatan) adalah mengenal kelebihan-kelebihan yang dimilikioleh suatu produk atau jasa yang akan diangkat sebagai suatu objek permasalahan, dalam hal ini adalah kelebihankelebihan yang dimiliki Rumah Makan Patinku. Kelebihannya diantaranya yaitu produk yang diolah jenis ikan Patin, ikan yang menjadi ciri khas makanan melayu di Rumah Makan Patinku 
diolah dengan olahan berbeda. Makanan menggunakan rempah-rempah yang alamidengan cara memasak yang tradisional.

b. Weakness (kelemahan) adalah segala hal yang menyangkut tentang kekurangan dan kelemahan dari Rumah Makan Patinku. Kelemahannya antara lain kemasan yang digunakan tidak sesuai dengan ukuran produk yang dijual, sehingga kurang higienis serta citra rumah makan tersebut tidak muncul.

c. Opportunities (peluang) adalah semua peluang yang mungkin bisa didapatkan oleh Rumah Makan Patinku. Peluangnya adalah bertambah jumlah pelanggan dari rumah makan tersebut. Rumah Makan Patinku bisa menjadi onjek wisata kuliner di Kota Medan atau mungkin saja bisa menjadi oleh-oleh khas Kota Medan.

d. Threats (ancaman) adalah segala hal yang sekiranya dapat menghambat perkembangan usaha dari Rumah Makan Patinku. Ancamannya adalah jika tidak melakukan pengembangan inovasi baik dari segi produk tetapi juga kemasan lambat laun rumah makan tersebut bisa tertinggal dengan usaha sejenis yang sudah lebih mengembangkan produk terutama dari segi kemasan.

\section{III.3.2. Target Audience}

a. Geografis, berdasarkan segmentasi geografis target dari perancangan kemasan produk Rumah Makan Patinku adalah masyarakat yang tinggal di Kota Medan, tidak dipungkiri masyarakat di luar Kota Medan yang dapat dijadikan buah tangan untuk pulang ke daerahnya.

b. Demografis, secara demografis target dari perancangan ini yaitu pria dan wanita mulai dari anak-anak hingga orang dewasa, karena produk yang dijual sangat aman dan sehat dengan olahan berbagai macam rempah-rempah dengan tingkat ekonomi rendah sampai atas dikarenakan harganya masih terjangkau.

c. Psikografis, secara psikografis target dari perancangan yaitu para pekerja kantor, orangorang yang hobi berwisata kuliner bersama keluarga dan teman yang ingin menikmati olahan ikan patin dengan rasa yang berbeda.

\section{III.4. Tahap Perancangan dan Penggrafisan}

Perancangan yang penulis lakukan melalui sketsa manual terlebih dahulu lalu digrafiskan kemudian akan dipilih satu sketsa yang terbaik dari setiap produk, lalu dari sketsa yang terpilih akan digrafiskan dengan menggunakan aplikasi komputer yakni Google Skecthup dan Corel Draw. Google Skecthup akan pengkarya gunakan untuk menggrafiskan kembali sketsa terpilih dalam bentuk tampilan tiga dimensi, sedangkan Corel Draw akan pengkarya gunakan membuat pemodelan grafis untuk dicetak.

Dalam melakukan perancangan, penulis juga menggunakan prinsip-prinsip dasar desain, seperti yang dikatakan oleh Sadjiman Ebdi Sanyoto (2009) dalam bukunya Nirmana Elemen-elemen Seni dan Desain yaitu:

1. Kesatuan/Unity, Kesatuan merupakan salah satu prinsip dasar tata rupa. Unity biasa juga disebut keutuhan. Seluruh bagian-bagian atau dari semua unsur/elemen yang disusun harus saling mendukung, tidak ada bagian-bagian yang mengganggu, sehingga antara rancangan produk dalam dan luar menjadi satu kesatuan yang utuh dan tidak dapat dipisahkan. Perancangan produk Rumah Makan Patinku nantinya akan menjadi satu kesatuan utuh baik dari desain kemasan, penempatan logo, dan pemilihan warna kotak.

2. Dominasi, Dominasi dalam karya seni biasa disebut penjajah atau yang menguasai. Namun, dominasi bisa juga disebut keunggulan, keistimewaan, keunikan, keganjilan, kelainan atau penyimpangan (anomali). Setiap karya seni harus memiliki dominasi agar 
menarik karena unggul, istimewa, unik, ganjil, maka akan menjadi menarik dan pusat perhatian, menjadi klimaks. Pada kemasan produk Rumah Makan Patinku nanti di bagian luar akan didominasi konsep daun pisang sebagai background kemasan untuk kotak nasi dan kotak ikan sedangkan bagian dalam akan memiliki keunikan, pada bagian untuk tempat sambal pada kotak ikan patin.

3. Keseimbangan, Keseimbangan merupakan salah satu prinsip dasar seni rupa. Karya seni/desain harus memiliki keseimbangan agar enak dilihat, tenang, tidak berat sebelah, tidak menggelisahkan, dan tidak menggelimpang. Ada beberapa jenis keseimbangan, antara lain adalah sebagai berikut:

a. Keseimbangan simetris, Keseimbangan simetris yaitu keseimbangan antara ruang sebelah kiri dan ruang sebelah kanan sama persis, baik dalam bentuk rautnya, besarnya ukuran, arah, warna, maupun teksturnya.

b. Keseimbangan memancar, Keseimbangan memancar sesungguhnya sama dengan keseimbangan simetri, tetapi kesamaan polanya bukan hanya di antara ruang sebelah kiri dan ruang sebelah kanan saja, melainkan juga antara ruang sebelah atas dan ruang sebelah bawah.

c. Keseimbangan sederajat, Keseimbangan sederajat, yaitu keseimbangan komposisi antara ruang sebelah kiri dan ruang sebelah kanan tanpa mempedulikan bentuk yang ada di masing-masing ruang. Jadi, meskipun memiliki bentuk raut yang berbeda, tetapi besarnya sederajat, misalnya bentuk raut lingkaran dengan bentuk raut segitiga dengan besaran yang sama.

d. Keseimbangan tersembunyi (asimetris), Keseimbangan tersembunyi sering kali disebut juga keseimbangan asimetris, yaitu keseimbangan antara ruang sebelah kiri dan ruang sebelah kanan meskipun keduanya tidak memiliki besaran sama maupun bentuk raut sama.

\section{III.4.1. Tampilan Sketsa Manual dari desain terpilih}

Pada tahap perancangan sketsa manual penulis memberikan masing-masing tiga desain alternatif yang akhirnya hanya ada satu desain terpilih dari setiap desain yang dirancang. Pada tulisan ini penulis hanya menampilkan masing-masing satu sketsa manual yang terpilih, dikarenakan terlalu banyak jika penulis menampilkan seluruh sketsa manual yang dirancang. Ada tujuh kemasan produk yang dirancang dalam perancangan kemasan produk Rumah Makan Patinku seperti yang telah dipaparkan sebelumnya, yakni pembungkus nasi, kotak nasi, kotak ikan Patin bakar, Stiker untuk plastik kontainer Patin Steam Tauco, paper bag, cup plastik, serta plastik bag. Berikut tampilan sketsa manualnya.

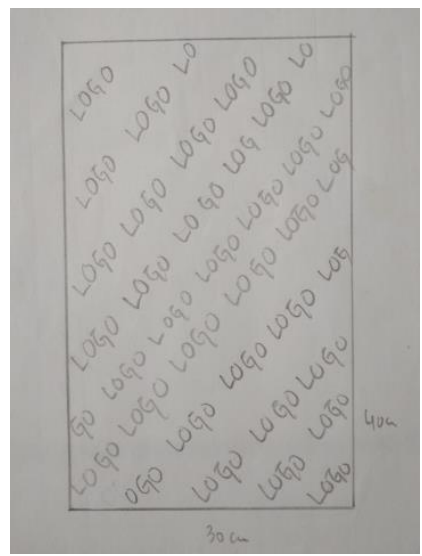

Gambar 1. Sketsa Manual terpilih Pembungkus Nasi Sumber : John, 2018 


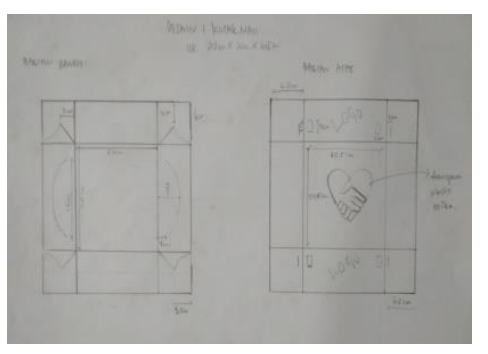

Gambar 2. Sketsa Manual terpilih Kotak Nasi Sumber : John, 2018

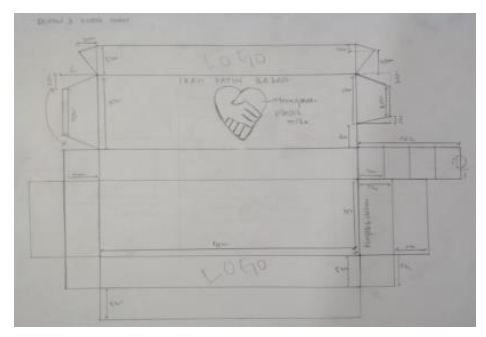

Gambar 3. Sketsa Manual terpilih Kotak Ikan Patin Bakar Sumber : John, 2018

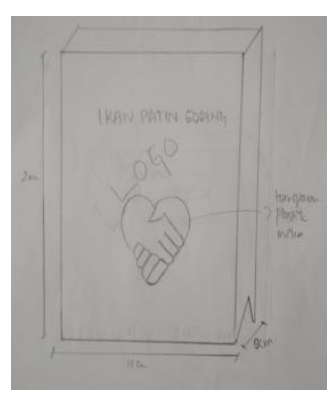

Gambar 4. Sketsa Manual terpilih Paper Bag Sumber : John, 2018

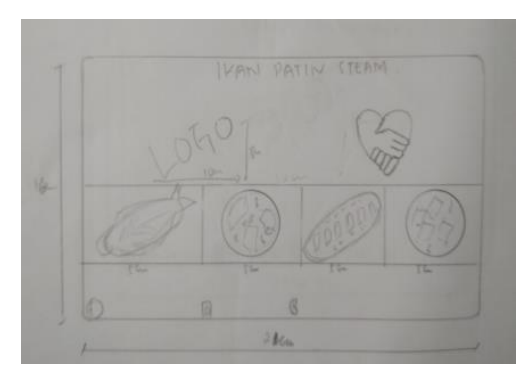

Gambar 5. Sketsa Manual terpilih Stiker Plastik Kontainer Sumber : John, 2018 


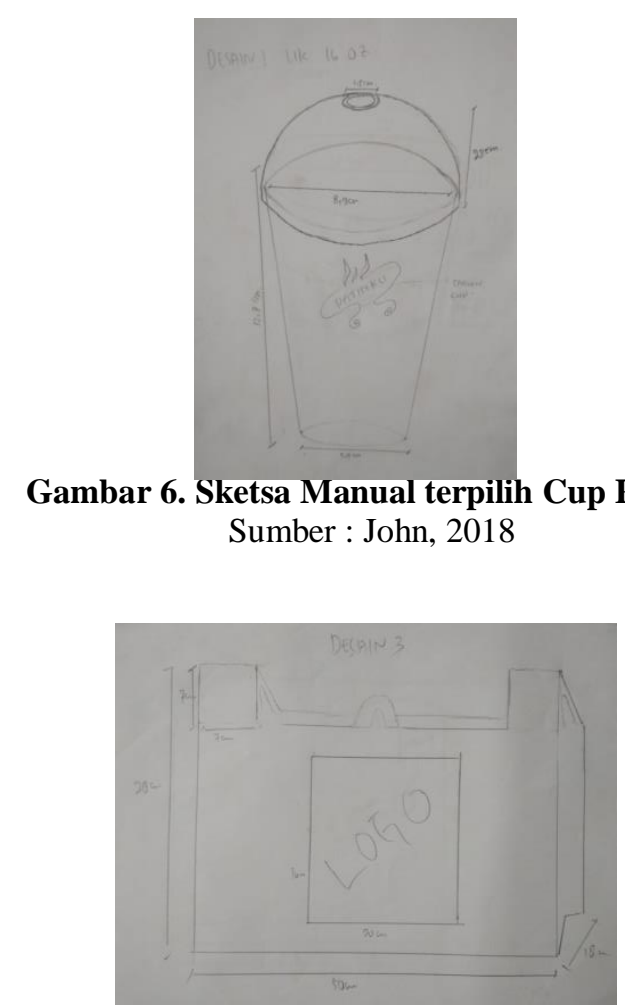

Gambar 7. Sketsa Manual terpilih Plastik Bag Sumber : John, 2018

\section{III.4.2. Tampilan Desain terpilih setelah digrafiskan}

Setelah pada tahap perancangan sketsa manual kemudian dilanjutkan ke tahap penggrafisan. Pada tahap ini penggrafisan dilakukan dengan menggunakan perangkat lunak Corel Draw untuk tampilan dua dimensi yang akan dicetak dan Google sketchup untuk tahap pemodelan tiga dimensi agar dapat terlihat tampilan bentuk ruang dari kemasan yang dirancang. Tahap penggrafisan juga menjadi tahapan yang penting karena jika salah dalam penggrafisan maka hasil yang dicetak di percetakan juga salah

Penggrafisan yang dilakukan juga digunakan untuk melihat tampilan sementara sebelum kemasan yang dirancang akan dicetak, sehingga jika ada yang ingin diperbaiki dari segi rancangan masih memungkinkan untuk dirubah. Berikut tampilan grafis dari sketsa yang terpilih baik dari segi tampilan dua dimensi maupun tiga dimensi

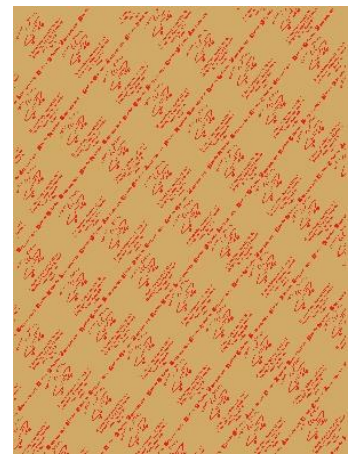

Gambar 8. Sketsa grafis terpilih Pembungkus nasi Sumber : John, 2018 

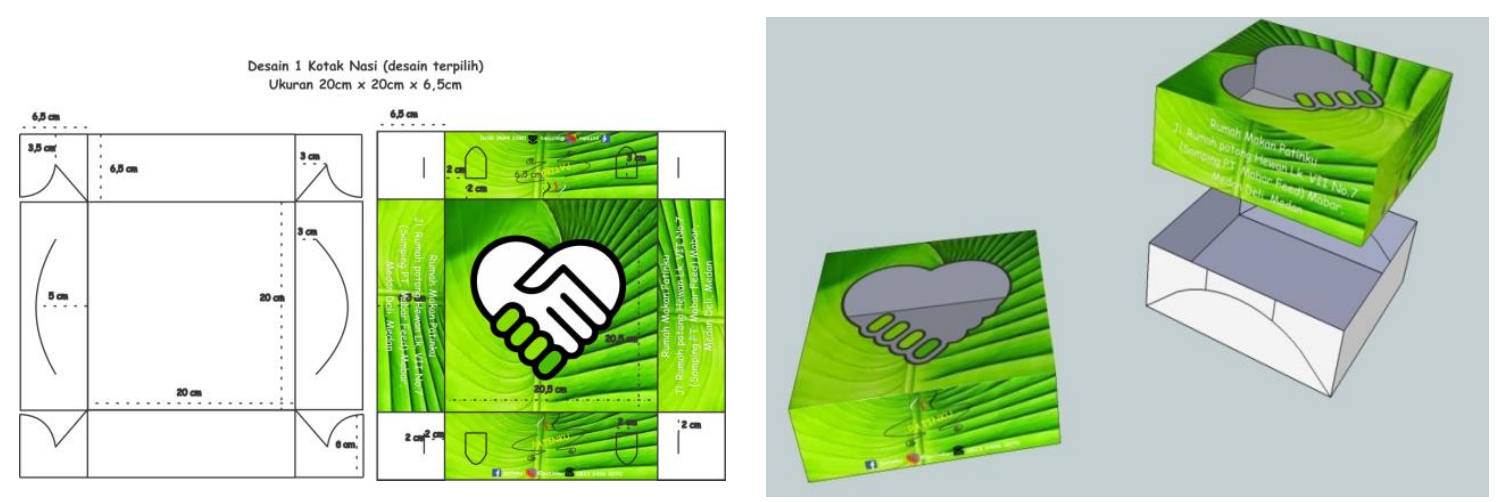

Gambar 9. Sketsa grafis terpilih Kotak nasi

Sumber : John, 2018

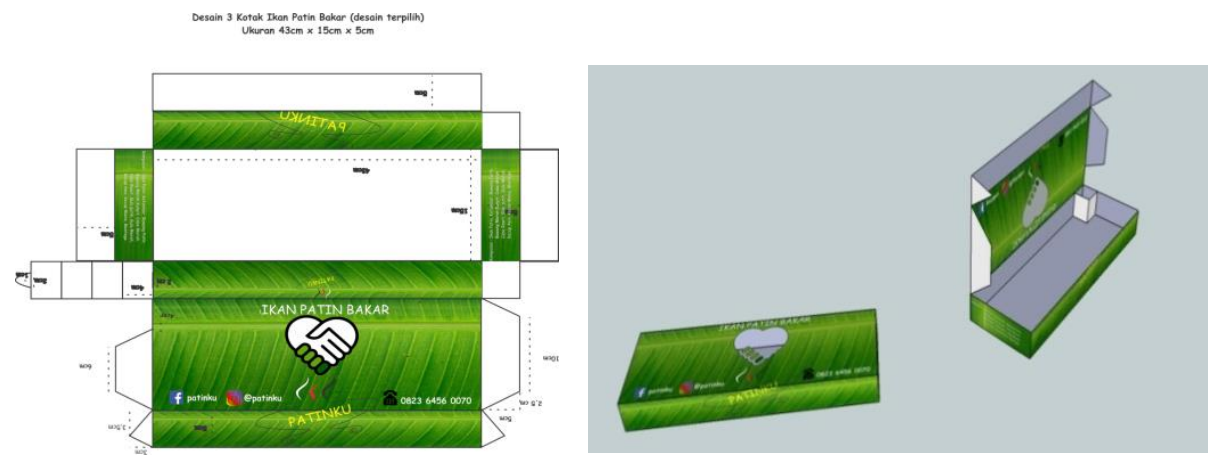

Gambar 10. Sketsa grafis terpilih Kotak Ikan Patin Bakar Sumber : John, 2018
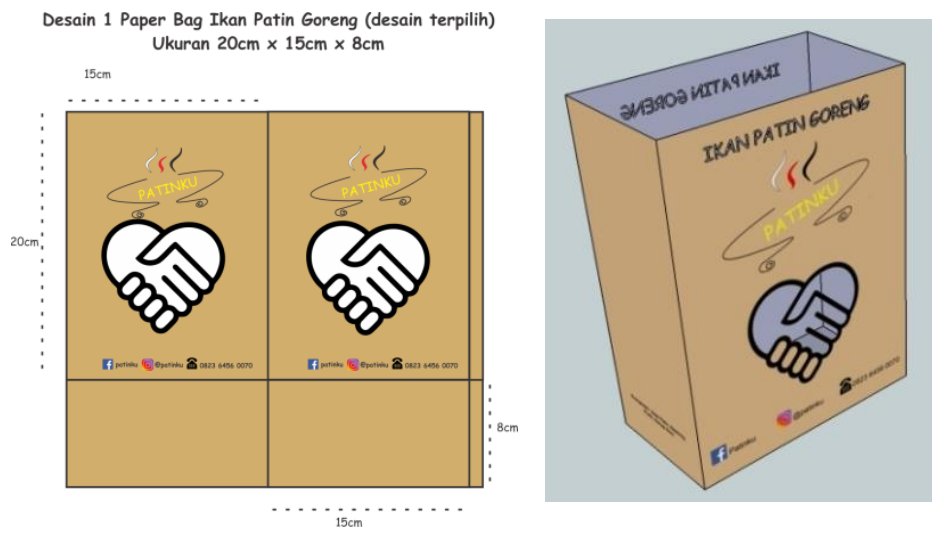

Gambar 11. Sketsa grafis terpilih Kotak Ikan Patin Bakar Sumber : John, 2018

Desain stiker 3 (desain terpilih) ukuran $21 \mathrm{~cm} \times 16 \mathrm{~cm}$
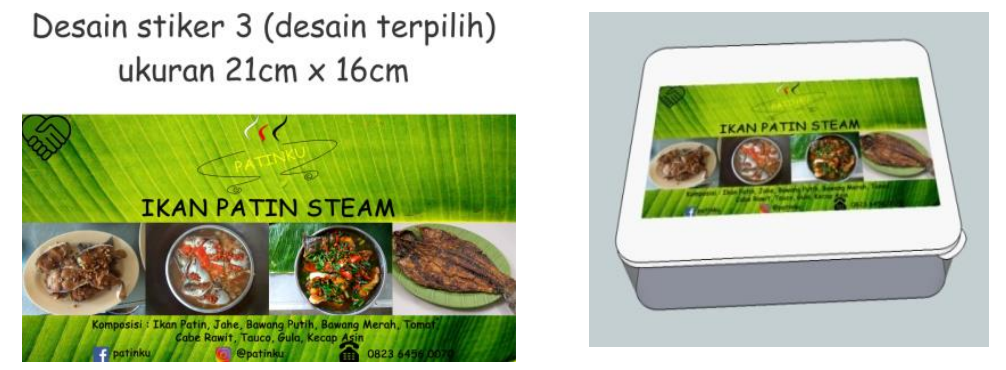

Gambar 12. Sketsa grafis terpilih Stiker Plastik Kontainer Sumber : John, 2018 

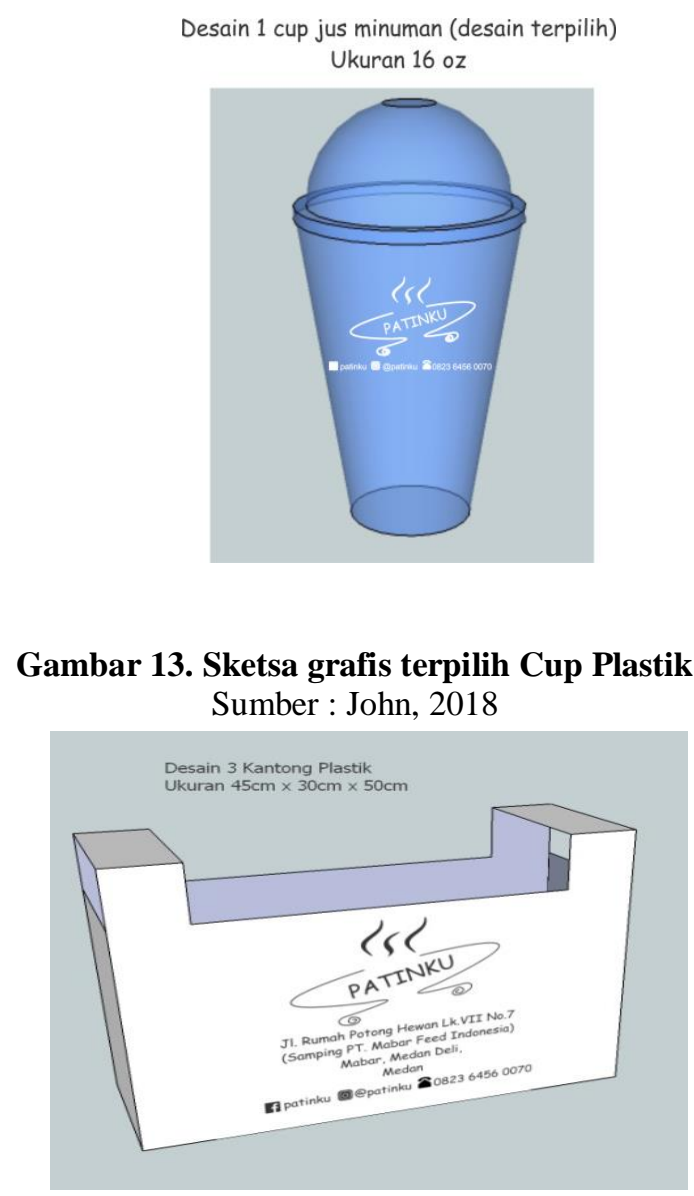

Gambar 14. Sketsa grafis terpilih Plastik Bag Sumber : John, 2018

\section{III.5. Tahap penciptaan hasil karya}

Hasil dari penggrafisan yang sudah selesai akan dilanjutkan untuk menciptakan kemasan dan stiker, penciptaan kemasan akan dibuat ke percetakan. Kemasan yang dihasilkan dan telah disetujui oleh pemilik usaha akan digunakan di Rumah Makan Patinku sebagai kemasan yang resmi.

Tahap percetakan dilakukan di beberapa percetakan di Indonesia, ada yang di Medan, Bukit Tinggi, bahkan sampai Tanggerang. Adapun percetakan dilakukan di beberapa tempat untuk mendapatkan hasil yang bagus dan mencari harga cetak yang sesuai dengan kemampuan Rumah Makan Patinku.

\section{III.6.Tipografi}

Tipografi dalam desain komunikasi visual dikatakan sebagai bahasa yang langsung terlihat, sedikit berbeda dengan simbol atau tanda yang menggambarkan sesuatu makna. Tipografi adalah salah satu sarana untuk menterjemahkan kata-kata yang terucap ke halaman yang dapat dibaca. Peranan dari tipografi adalah untuk mengkomunikasikan ide atau informasi dari simbol atau tanda tertentu ke pengamat. Secara tidak sadar manusia selalu berhubungan dengan tipografi setiap saat.

Kusrianto menjelaskan tipografi adalah bidang ilmu yang mempelajari seluk- beluk mengenai huruf, yang mempunyai dua fungsi, yaitu sebagai fungsi estetis dan fungsi 
komunikasi, sebagai fungsi estetis, tipografi digunakan untuk menunjang penampilan sebuah pesan agar terlihat menarik, sedangkan sebagai fungsi komunikasi tipografi untuk menyampaikan pesan (informasi) berupa teks dengan jelas dan tepat. (Kusrianto,2007:76)

Tabel 1. Alternatif Tipografi pada Kemasan

\begin{tabular}{|c|c|c|c|}
\hline Contoh Kata & Jenis Font & Bentuk Huruf & Font Terpilih \\
\hline $\begin{array}{l}\text { IKAN PATIN } \\
\text { BAKAR }\end{array}$ & Cambria & $\begin{array}{l}\text { ABCDEFGHIJKLMNOPQRSTUVWXYZ } \\
\text { 0123456789,,';"!? }\end{array}$ & $\mathrm{X}$ \\
\hline $\begin{array}{l}\text { IKAN PATIN } \\
\text { BAKAR }\end{array}$ & Times New Roman & $\begin{array}{l}\text { ABCDEFGHIJKLMNOPQRSTUVWXYZ } \\
0123456789, \cdot ; ; ! ?\end{array}$ & $\mathrm{X}$ \\
\hline $\begin{array}{l}\text { IKAN PATIN } \\
\text { BAKAR }\end{array}$ & ALGERIAN & $\begin{array}{l}\text { ABCDEFGHIJKLMNOPQRSTUVWXYZ } \\
\text { 0123456789,.;;"!? }\end{array}$ & $\mathrm{X}$ \\
\hline $\begin{array}{l}\text { IKAN PATIN } \\
\text { BAKAR }\end{array}$ & Comic Sans Ms & $\begin{array}{l}\text { ABCDEFGHIJKLMNOPQRSTUVWXYZ } \\
0123456789,,: ; ! ! ?\end{array}$ & $\checkmark$ \\
\hline $\begin{array}{l}\text { IKAก PATIN } \\
\text { BAKAR }\end{array}$ & Bauhaus 93 & $\begin{array}{l}\text { ABCDEFGHIJKIMNOPORSTUVWXYZ } \\
0123456789 . . \therefore: \cdots ! ?\end{array}$ & $\mathbf{x}$ \\
\hline
\end{tabular}

\section{III.6.Warna}

Pada dasarnya warna adalah suatu mutu cahaya yang dipantulkan dari suatu objek ke mata manusia. Hal ini menyebabkan kerucut-kerucut warna pada retina bereaksi, yang memungkinkan timbulnya gejala warna pada objek-objek yang dilihat sehingga dapat mengubah persepsi manusia. Warna bersifat subjektif karena warna memiliki hubungan yang sangat kuat dengan setiap individu yang melihatnya. Dalam hubungannya dengan logo, warna merupakan elemen yang sangat penting dalam peranannya sebagai media pengingat. Warna juga adalah unsur yang sangat penting dalam menyentuh kepekaan indera penglihatan agar dapat mempengaruhi perasaan, perhatian, dan minat seseorang.(Kusrianto, 2007:46). 


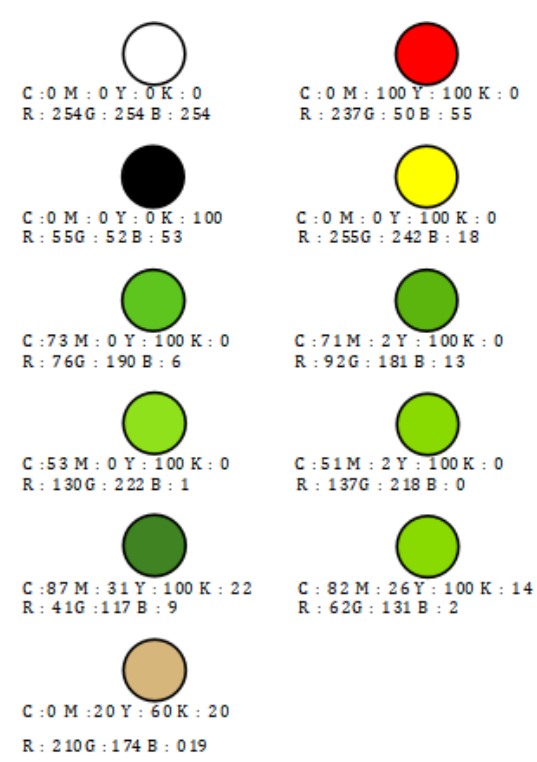

Gambar 15. Warna yang digunakan pada kemasan produk Rumah Makan Patinku Sumber : John, 2018

\section{KESIMPULAN}

Berdasarkan hasil penelitian dengan judul "Perancangan Kemasan Produk Rumah Makan Patinku di Medan" dapat ditarik kesimpulan bahwa kemasan bukan hanya sebagai pembungkus produk namun juga sebagai media komunikasi yang efektif. Melalui kemasan yang menarik maka perusahaan atau pemilik usaha dapat menyampaikan citra, visi, dan misi dari usaha yang dijalankannya. Kemasan juga bukan hanya digunakan sebagai pelindung dari produk yang ada di dalamnya namun juga memiliki nilai estetis dari yang merancangnya.

Sebelum konsumen menikmati produk sudah tentu mereka akan melihat kemasan yang melindungi produk tersebut, sehingga jika dari tampilan kemasan kurang menarik maka konsumen sudah enggan untuk membeli produk yang dijual. Kemasan juga membuat nilai jual dari produk meningkat karena tampilan menarik dari kemasan akan secara bersamaan akan menambah nilai jual dan kualitas dari produk yang dijual.

\section{DAFTAR PUSTAKA}

[1] Christina, Jovita et al. 2017. "Perancangan Desain Kemasan Produk Ledre'Ny. Seger"”. Jurnal DKV Adiwarna Vol 1, hal :32-42.

[2] Departemen Pendidikan Nasional.2008. Kamus Besar Bahasa Indonesia. Pusat Bahasa : Jakarta

[3] Handojo, Roy Grace et al. 2016. "Perancangan Kemasan Inovatif Gado-Gado Arjuna Pak Satumin Surabaya”. Jurnal Desain Komunikasi Visual Adiwarna Vol 1 No.8, hal. $1-9$. 
[4] Klimchuk, Marianner Rosner dan Sandra A. Krasovec. 2007. Desain Kemasan. Erlangga: Jakarta.

[5] Kotler, Philip dan Gary Armstrong. 2008. Prinsip-prinsip Pemasaran. Jilid 1. Jakarta: Erlangga.

[6] Kusrianto, Adi. 2007. Pengantar Desain Komunikasi Visual. Yogyakarta: Andi Offset.

[7] Moleong, Lexy J. 1996. Metodologi Penelitian Kualitatif. Bandung : Remaja Rosda Karya.

[8] Natadjaja, Listia et al. 2014. "Makna pada Teks Desain Kemasan Jamu Khusus Wanita". Jurnal Bahasa dan Seni Tahun 42, No.1, hal. 51-65.

[9] Pamela, Apsari Wiba dan Oki Hamka Suyatna. 2014. "Perancangan Kemasan Produk Perawatan Kulit Gizi Indonesia". Jurnal Tingkat Sarjana Bidang Senirupa dan Desain Vol 3, No. 1, hal : 1-8.

[10] Sanyoto Ebdi, Sadjiman. 2009. Nirmana Dasar-dasar Seni dan Desain. Yogyakarta : Jalasutra.

[11] Sarwono, Jonathan dan Hary Lubis. 2007. Metode Riset untuk Desain Komunikasi Visual. Yogyakarta : Andi Offset.

[12] Wahyudi, Rizqi et al. 2013. "Analisis Mutu dan Kemasan Lempuk Durian (Durio Zibethinus Sp)". Jurnal Industri, Vol 2 No.1, hal:1-8. 